\title{
FENOMENOLOGIA PARA UMA MORAL
}

Gustavo Fujiwara ${ }^{1}$

Beatriz Viana de Araujo Zanfra²

\begin{abstract}
Resumo: Nosso objetivo neste trabalho é, por meio das noções de Cogito e Ego tais como elaboradas por Jean-Paul Sartre, traçar um itinerário investigativo tendo como suporte principalmente as obras $A$ Transcendência do Ego e Esboço de uma teoria das emoções que nos permita chegar a uma moral definida em bases fenomenológicas, ou ainda uma moral que lide com a liberdade à qual, segundo Sartre, todos nós estamos condenados. Tendo apenas a pretensão de fornecer uma orientação preliminar a tal tema, a atenção de nosso estudo se volta sobretudo para a maneira como Sartre demonstra o Cogito como originariamente desprovido de um Eu para a partir daí mostrar como se dá a constituição do Eu, o que desembocará numa concepção mais aprofundada da consciência e numa teoria das emoções.
\end{abstract}

Palavras-chave: consciência - Ego - fenomenologia - moral - liberdade

\begin{abstract}
Our objective in this work is, by means of the Cogito and Ego notions, such as elaborated by Jean-Paul Sartre, draw an investigative itinerary being supported mostly by Sartre's works The Ego Transcendence and Outline of a Theory of emotions that allows us to reach a moral defined in phenomenological bases, or a moral that deals with the liberty to which, according to Sartre, we are all doomed. Having a claim to provide a preliminary orientation to such topic, the attention of our study turns especially to the way Sartre demonstrates the Cogito as originally devoid of a self in order to show from there how is the constitution of the self, which will lead to a further conception of consciousness and a theory of emotions.
\end{abstract}

Keywords: consciousness - Ego - phenomenology - moral - liberty

\section{INTRODUÇÃO}

O Ego, evocação moderna do sujeito do conhecimento, sempre esteve presente na Filosofia. Indo além, ele inspirou incontáveis páginas da história do pensamento humano. Descartes, o célebre filósofo francês do século XVII, depois de muito duvidar e cair em um estado de dúvida hiperbólica, faz emanar o Cogito ergo sum. Por meio da dúvida, essa primeira certeza que é indubitavelmente verdadeira funda um novo alicerce para o edifício do conhecimento.

No século XX, Sartre, adepto da fenomenologia husserliana, nos dirá em seu ensaio

\footnotetext{
1 Doutorando em Filosofia na Universidade Federal de São Paulo, bolsista da FAPESP.

2 Doutoranda em Filosofia na Universidade Federal de São Paulo.
} 
A Transcendência do Ego que o Ego é transcendente, ou seja, que ele não faz parte da estrutura originária da consciência. Ele, o Ego, é apenas um fenômeno, objeto que habita o mundo tal qual o Ego de outrem.

Pretendemos primeiramente evocar a noção de Cogito, e, por conseguinte, a de Ego na filosofia sartreana. Nosso esforço aqui será duplo: de um lado precisamos apresentar o Cogito desprovido de um Eu e mostrar de que maneira se constitui esse Eu. Nosso texto, portanto, pretende elucidar os caminhos que possibilitaram a Sartre desprover a consciência de um Eu. Num segundo momento, traremos à luz Esboço de uma teoria das emoções, também de autoria do filósofo, escrito que nos aprofundará na concepção sartreana da consciência, e, por conseguinte, na concepção das emoções.

Em ambos os escritos, Sartre parece apontar para certo tipo de ofuscamento que a própria consciência faz de si. Ao temer a liberdade à qual estamos todos condenados, nossas ações se escondem e se justificam por meio de um Eu ou por meio de uma emoção que altera a ordem do mundo objetivo. Parece-nos que o filósofo abre caminho para certo modo de ser do homem, diante da concretude do mundo, caminho este que terá seu desenvolvimento crucial em seu livro intitulado $O$ Ser e o Nada. Será que podemos, diante da concepção sartreana de Cogito, apontar para uma moral que lida com a liberdade que nos perpassa de ponta a ponta? Pelas vias fenomenológicas é plausível definir uma nova moral?

\section{A INTENCIONALIDADE}

As páginas do ensaio A Transcendência do Ego, de Jean-Paul Sartre, fazem parte dessa história do Ego que citamos acima. Debrucemo-nos sobre elas. Na primeira parte do ensaio, o filósofo já nos mostra o projeto que ambiciona realizar. Lemos:

Para a maior parte dos filósofos, o Ego é um "habitante" da consciência. Alguns afirmam sua presença formal no seio dos "Vividos" como um princípio vazio de unificação. [...] Nós queremos mostrar aqui que o Ego não está na consciência nem formal nem materialmente: ele está fora, no mundo; é um ser do mundo, tal como o Ego de outrem. ${ }^{3}$

Destarte, por meio deste trecho inicial, Sartre pretende mostrar que o Ego é um habitante do mundo e que, por conseguinte, não faz parte da estrutura da consciência. Portanto, trata-se de saber por que uma consciência que, em si mesma, não é dotada de qualquer estrutura egológica pode constituir um objeto como o Ego e pode se afirmar idêntica a ele, como sendo ele. A abordagem do conceito sartreano de Ego não pode ser feita sem a apresentação prévia de alguns aspectos de sua teoria da consciência. Se assim

3 Sartre, J.P. A transcendência do ego. Tradução de Pedro M.S. Alves. Edições Colibri. Lisboa. 1994. p 43. 
é, devemos retornar ao seu famoso texto "Uma ideia fundamental da fenomenologia de Husserl: a intencionalidade"4.

Nesse artigo, o filósofo descreverá o que é a intencionalidade da consciência para que assim ele possa recolocá-la enquanto espontaneidade absoluta. Contra a epistemologia clássica, contra uma filosofia da ciência racionalista e reflexiva, a visão do próprio ato de conhecer era turvada por um ponto de partida errôneo, ou seja, tudo era reduzido aos chamados "conteúdos de consciência". Lemos:

O que é uma mesa, um rochedo, uma casa? Certa montagem de "conteúdos de consciência", certa ordem desses conteúdos. Oh, filosofia alimentar! Nada parecia, no entanto, mais evidente: a mesa não é o conteúdo atual de minha percepção, minha percepção não é o estado presente de minha consciência? ${ }^{5}$

Contra tal filosofia do espírito alimentar, Sartre anuncia a intencionalidade da consciência, tal qual fora pensada por Husserl. Com ela, a consciência e o mundo não são mais redutíveis ou substituíveis, mas cada instância resguarda seu modo de ser fundamental. Com a ideia de intencionalidade, a consciência se vê livre de qualquer conteúdo retido em seu interior. A consciência é agora pura atividade, um nada que é tudo. Entendamos: ela visa os objetos imediatamente, mas não os retém para si. Ela é tudo porque é só por meio dela que apreendemos os objetos transcendentes, é por meio dela que o objeto se coloca em presença. Nos dizeres de Husserl: apreendemos o objeto em carne e osso. O Cogito, por meio da noção de intencionalidade, nos lança na concretude do mundo dos vividos (Erlebnis).

A intencionalidade da consciência faz parte de sua estrutura originária. A partir disso, temos como resultado a seguinte cláusula fenomenológica: "toda consciência é consciência de um objeto qualquer" " ${ }^{6}$. A certeza de que toda consciência é consciência de um objeto é também a certeza de que todo objeto é objeto para uma consciência. Por meio da intencionalidade a consciência volta a ser translúcida, fato absoluto que coincide com a própria vida. É preciso salientar ainda que o ato de apreender um objeto no mundo faz com que a consciência transcenda a si mesma a todo instante. Portanto, ela não está mais aprisionada, mas se apresenta como fundadora da realidade porque é por meio dela que os objetos transcendentes se colocam diante de nós. Destarte, o real é aquilo que a liberdade da consciência funda. Sartre dirá sobre a consciência:

\footnotetext{
4 Agradecemos ao professor doutor Alexandre de Oliveira Torres Carrasco que gentilmente disponibilizou tradução própria do texto referido.

5 Sartre, J.P. "Uma ideia fundamental da fenomenologia de Husserl: a intencionalidade". Tradução de Alexandre de Oliveira Torres Carrasco.

6 Esta cláusula primeira da fenomenologia deve ser entendida como a consciência irrefletida, originária.
} 
[...] ela não é nada senão o fora dela mesma e é esta fuga absoluta, essa recusa de ser substância que a constitui como consciência. [...] "Toda consciência é consciência de alguma coisa". Nada mais é necessário para pôr termo à filosofia doce e comportada da imanência onde tudo se faz por compromisso, troca protoplasmática, por uma morna química celular. A filosofia da transcendência nos atira na estrada principal, no meio de ameaças, sob uma luz que cega. ${ }^{7}$

Logo, a consciência é pura atividade que, ao se transcender constantemente, foge de si mesma, se lança para o mundo dos objetos donde eles se colocam diante dela com uma proximidade absoluta. Como já dissemos, mas é importante sublinhar para que depois possamos retomar essa ideia, a consciência é um nada que é tudo. A partir da noção de intencionalidade, a consciência passa a ser um vazio, um nada, daí dizer que ela não pode ter em sua estrutura um Ego. Devemos sublinhar que a intencionalidade dispensa um núcleo unificador e deve ser incompatível com esse núcleo. Portanto, o $\mathrm{Ego}^{8}$ não pode ser um elemento que unifica as consciências. Pedro M. S. Alves definiu de maneira extraordinária o que significa a intencionalidade. Lemos:

Ora a intencionalidade, a tese de que toda consciência é sempre consciência de, não deve ser rebaixada ao nível de uma afirmação banal e sem relevância. O que ela estatui não é simplesmente que toda consciência é sempre consciência de qualquer coisa [...]; o que ela verdadeiramente diz, por detrás dessa afirmação anódina e trivial, é que a consciência é sempre e só consciência, e que o é plenamente. "Toda consciência é consciência de qualquer coisa" tem na verdade este significado essencial: nada há na consciência que não seja consciência, ela está toda contida na sua relação ao objeto intencional, tudo nela é ato, não havendo aí nada semi ou inconsciente. ${ }^{9}$

Essa noção garante que a consciência seja exclusivamente um movimento interrupto para fora de si e que seja consciência na exata medida em que é consciência de um objeto. A intencionalidade, tal qual apresentamos aqui, será retomada no ensaio. Por isso, retornemos a ele.

\footnotetext{
7 Id., ibid. Grifo nosso.

8 Sobre isso, falaremos mais adiante, retomando o ensaio A Transcendência do Ego. Por ora, o que queremos marcar é que com a ideia de intencionalidade a consciência se torna um vazio, um nada que se transcende constantemente.

9 ALVES, M. S. Pedro. Irrefletido e Reflexão - Observações sobre uma tese de Sartre. Edições Colibri. Lisboa. 1994, pg. 18.
} 


\section{COGITO E EGO TRANSCENDENTAL}

Na seção “A teoria formal da presença do Eu”, Sartre recusará uma presença mesmo que formal do Ego. Segundo a filosofia kantiana, "o eu penso deve poder acompanhar todas as nossas representações", ou seja, para Kant o Eu deverá poder acompanhar todas as representações e por isso receberá o estatuto transcendental. Desse modo, não será possível conhecê-lo objetivamente porque nenhum conteúdo de afecção empírica nos é dado que revele esse sujeito. O Ego transcendental kantiano é condição de possibilidade de toda e qualquer síntese, ele é polo unificador que irá unificar as categorias de síntese. O problema exposto nessa primeira seção é que o neokantismo francês toma como realidade aquilo que o próprio Kant institui somente como possibilidade.

Se quisermos responder a perguntas como: "o Eu que nós encontramos na nossa consciência é tornado possível pela unidade sintética de nossas representações ou é antes ele que unifica de fato as representações entre si?" ${ }^{10}$ deveremos nos desvencilhar do embaraço provocado pelos neokantianos e seguir a trilha da fenomenologia que se apresenta como um estudo científico e não crítico da consciência. Ela é um estudo dos fatos de consciência, portanto uma ciência que nos faz retornar às coisas mesmas pelo processo da intuição. Para Sartre, essa ciência descritiva traz consigo algo de novo, qual seja, a intuição ou, se quisermos, a intencionalidade que já vínhamos descrevendo algumas linhas acima. Vale dizer que os problemas que a consciência tem com o Eu são problemas existenciais, logo, factuais.

Nesse primeiro movimento do texto, Sartre irá elencar quatro pontos que deverão ser respondidos sobre o Cogito e o Eu. Primeiro, o campo transcendental ${ }^{11}$ deverá se apresentar impessoal, ou, se quisermos, a consciência terá de ser desprovida de um Eu, o que significa dizer que a consciência é constituinte e o Eu constituído. Em seguida, o Eu deverá aparecer com uma função psíquica. Depois, é preciso que esse Eu não contribua para criar esse fundo sobre o qual ele aparece, mas, ao contrário, seja esse fundo que faz com que ele apareça. Por último, é preciso responder se um Eu, mesmo abstrato, acompanha necessariamente uma consciência ou se não podemos conceber consciências absolutamente impessoais.

Para poder responder a essas teses, o filósofo francês se utilizará da espontaneida$\mathrm{de}^{12}$. É intrínseco fazer notar que a intencionalidade nos faz entender que a consciência é

10 Sartre, J. P. A transcendência do ego. Tradução de Pedro M.S. Alves. Edições Colibri. Lisboa. 1994. p 45. 11 O campo transcendental pode ser entendido como uma camada, uma esfera originária que institui por meio dos atos da consciência o sentido.

12 "Com efeito, a consciência define-se pela intencionalidade. Pela intencionalidade, ela transcende-se a si mesma, ela unifica-se se escapando." A Transcendência do Ego, p. 47. 
consciência de si na exata medida em que é consciência de um objeto transcendente, ou seja, ela tem consciência sobre si mesma, sem precisar de um Eu para isso.

Mostremos então de que maneira o Eu será concebido como um objeto transcendente. É a consciência que se unifica a si mesma, ela não precisa de um Eu para realizar essa operação, isso decorre porque em sua estrutura original há a intencionalidade que dispensa um núcleo unificador. Lemos:

Conceber uma instância transcendental pessoal, que unifique toda consciência, envolve o risco de fazer dessa instância uma espécie de inconsciente - uma consciência inconsciente, paradoxo derivado do deslizamento para a esfera do psíquico do sentido de campo transcendental. ${ }^{13}$

Como já denotamos no artigo "Uma ideia fundamental...", o Cogito deverá ser intencional, constante fuga de si mesmo, um vazio, um nada que é tudo; no ensaio, Sartre acrescenta que a consciência não pode ser limitada a não ser por ela mesma, ela constitui uma totalidade sintética e individual inteiramente isolada das outras totalidades do mesmo tipo e que "o Eu não pode ser senão uma expressão (e não uma condição) desta incomunicabilidade e interioridade das consciências" ${ }^{14}$. Caso concebêssemos um Eu na estrutura da consciência, isto seria declarar sua morte, posto que ela deixaria de ser translúcida, vazia e intencional.

A título de mostrar como a consciência pode ser consciência de si, voltemo-nos neste instante para a seção intitulada "O cogito como consciência reflexiva". Nessa seção, Sartre irá descrever o modo pelo qual a consciência pode apreender a si mesma, e isso se deve ao fato reflexivo do Cogito. Destarte, há uma consciência de segundo grau que é ela mesma tomada enquanto objeto, ou seja, há uma consciência dirigida sobre a consciência que a toma como objeto.

Para o filósofo, existe uma consciência irrefletida, que, como já dissemos, é a cláusula primeira da fenomenologia ${ }^{15}$, ou seja, através de sua espontaneidade coloca os objetos transcendentes em nossa presença. Portanto, a consciência irrefletida é apenas consciência do objeto transcendente. O segundo grau da consciência, também denominada consciência reflexionante, se reflete sobre a consciência irrefletida. Em ambos os casos, há consciência de si. No primeiro, espontânea e não posicional; no segundo, consciên-

\footnotetext{
13 SILVA, Franklin Leopoldo e. Ética e Literatura em Sartre: Ensaios introdutórios. São Paulo: UNESP, 2004 , p. 38.

14 Sartre, J.P. A transcendência do ego. Tradução de Pedro M.S. Alves. Edições Colibri. Lisboa. 1994. p 48

15 "Toda consciência é consciência de um objeto qualquer." Logo, esse nível irrefletido é, assim, colocado à posição de uma forma canônica e absolutamente autônoma.
} 
cia posicional da consciência refletida. Usemos um exemplo: leio um livro e posiciono as palavras e o sentido das frases, mas sem posicionar o ato de ler propriamente dito, (consciência irrefletida espontânea e não posicional). De súbito, alguém me pergunta o que estou fazendo. Cesso a leitura, faço uma reflexão e respondo que estava lendo. Nesse momento, tive consciência de ter consciência de minha leitura (consciência reflexionante espontânea e posicional). Em ambos os casos, tanto no plano irrefletido como no plano reflexionante, o que operava em mim era a mesma consciência, ora sendo apenas consciência não posicional do exercício da leitura, ora, quando interrompido e questionado sobre o que fazia, como consciência de ter consciência da leitura. Devemos salientar que em ambos os planos há consciência espontânea do objeto livro.

Explicitado o mecanismo, Sartre atenta para o fato de que o Eu surge na passagem da consciência de primeiro grau à consciência reflexionante. Todavia, ele não é anterior à consciência do objeto: antes, é posto pela consciência reflexionante à maneira de um objeto. Assim, é a consciência reflexiva aquela que capta o Eu penso ${ }^{16}$.

[...] a certeza do Cogito é absoluta pois, como o diz Husserl, há uma unidade indissolúvel da consciência reflexionante e da consciência refletida (a tal ponto que a consciência reflexionante não poderia existir sem a consciência refletida). Não é menos verdade que estamos na presença de uma síntese de duas consciências, das quais uma é consciência da outra. Assim, o princípio da fenomenologia, "toda consciência é consciência de qualquer coisa", está salvaguardado. ${ }^{17}$

Não há Eu no plano da consciência irrefletida nem no plano da consciência reflexionante, ela permanece pura atividade, estou no mundo dos objetos e "são eles que constituem a unidade que posso encontrar na consciência que deles tenho" ${ }^{18}$. A lei para a existência do Cogito é que ele seja consciência de si na exata medida em que é consciência dos objetos. Por isso, Sartre escreve:

O Eu transcendental é a morte da consciência. Com efeito, a existência da consciência é um absoluto porque a consciência está consciente dela mesma. Isto quer dizer que o tipo de existência da consciência é o de ser consciência de si. E ela toma consciência de si enquanto ela é consciência de um objeto transcendente. ${ }^{19}$

\footnotetext{
16 É interessante frisar que o Eu penso cartesiano não é o eu que pensa. Descartes, assim nos parece, atribui ao cogito somente sua estrutura reflexiva.

17 Id., ibid, p. 50.

18 Silva, Franklin Leopoldo e. Ética e Literatura em Sartre: Ensaios introdutórios. São Paulo: UNESP, 2004, p. 41

19 Sartre, J.P. A transcendência do ego. Tradução de Pedro M.S. Alves. Edições Colibri. Lisboa. 1994. p. 48
} 
Tudo é claro e translúcido na consciência, os objetos estão em face dela com sua opacidade característica, mas a consciência é simplesmente consciência de ser consciência desses objetos: ela os põe e os apreende. Assim sendo, o visado coincide com o apreendido. Por meio disso tudo, podemos finalmente dizer que o Eu não cria o mundo, nem tampouco o mundo determina o Eu: ambos são fenômenos que se mostram para a consciência, que é impessoal.

Deve ficar claro agora que a passagem do polo irrefletido para o polo reflexionante da consciência constitui as bases para a aparição do Ego transcendente. Na operação reflexiva, apreendemos um $\mathrm{Eu}$, mas, vale ressaltar, que o apreendemos com o "canto do olho". Ele aprece nessa passagem do plano irrefletido ao plano reflexivo ${ }^{20}$, mas ele continua sendo ainda um objeto transcendente que não participa daquele processo nem o unifica. Tornemos nítido: o Cogito é unidade indissolúvel da consciência reflexionante com a consciência refletida. Dessa maneira, fica claro que ser consciência consciente de um objeto é um duplo efeito gerado pela estrutura originária da consciência (irrefletida) e que um Eu é apreendido apenas no plano reflexionante, mas continua sendo ainda um objeto transcendente.

Segundo Sartre, portanto, o Eu aparece somente em um ato reflexivo, é o objeto transcendente desse ato reflexivo. O Ego é um existente e "sua realidade transcende a consciência, tal como a realidade dos objetos, dos quais ele evidentemente se diferencia $^{21}$ ". Atestamos disso a seguinte conclusão, qual seja, o Ego não é e jamais poderá fazer parte da unidade da consciência refletida (objeto) e da consciência reflexionante (ação) porque, como vínhamos mostrando anteriormente, essas consciências prescindem de tal Ego, dada a espontaneidade e seu mecanismo originário (consciência consciente de um $\mathrm{X}$ qualquer). Podemos afirmar que a consciência sem Eu é um absoluto impessoal e não-substancial e que o Ego é estéril no processo da consciência. O filósofo escreve:

O Eu é um existente e sua realidade transcende a consciência, tal como a realidade dos objetos, dos quais ele evidentemente se diferencia. Tenho, portanto, intuição do Eu, que é também diferente da intuição dos demais objetos. É uma intuição que ocorre na consciência refletida, quando captamos o nosso próprio Eu de maneira fugidia - com o "rabo do olho", como diz Sartre. ${ }^{22}$

Além desse excerto, a título de nos aprofundarmos nesse Ego duvidoso, lemos:

20 Acerca dessa operação, Franklin Leopoldo Silva, em seu livro Ética e Literatura em Sartre, dirá: "Sartre chama a atenção para o fato de que o Eu surge na passagem da consciência irrefletida para a consciência reflexionante."

21 Silva, Franklin Leopoldo. Ética e Literatura em Sartre: Ensaios introdutórios. São Paulo: UNESP, 2004, p. 41. 22 Id., ibid, p. 41. 


\begin{abstract}
Além disso, no caso sartreano, as operações da consciência irrefletida ou do cogito pré- reflexivo passam pelas formas intuitivas adequadas do vivido (Erlebnis), elas serão, portanto, reguladas pelo instante e não pela temporalidade; daí sua apoditicidade, sua necessidade e sua indubitabilidade. Ora, o Ego (e, por extensão, a vida reflexiva), ao se caracterizar como intrinsecamente duvidoso, será regulado pelo modelo da percepção - cada Abschattung dando-se inadequadamente prefigura uma profundidade inesgotável. O peculiar e o próprio dessa versão sartreana está no rigor da clivagem, que assevera a irracionalidade postulada do Ego porque sua incompletude performativa - intuição inadequada, apresentação por perfis - (...) ${ }^{23}$
\end{abstract}

O que encontramos citado nesse trecho é o fato de que a consciência em seu nível irrefletido passa pela forma intuitiva adequada do vivido, o objeto é imediatamente visado e coincide com o apreendido. Essa operação se apresenta como sendo da ordem do instante, logo, podemos tirar disso seu caráter de necessidade e indubitabilidade. O Ego, de maneira duvidosa, se caracteriza pela percepção, ele é o extrato de uma intuição inadequada.

Fundado o mecanismo da consciência, é preciso, neste momento, definir o Ego e o modo como ele aparece de forma distinta dos objetos. O que sabemos por enquanto é que ele é também um objeto transcendente transportado para o fluxo das vivências, ele é algo que se apreende através de tal fluxo; fazemos do Eu uma unidade noemática e não uma dimensão noética da consciência.

\title{
O MODO DESINENCIAL DO EGO E A VERTIGINOSA LIBERDADE DA CONSCIÊNCIA
}

No capítulo II, intitulado "Constituição do Ego", o filósofo nos mostrará que o Eu é uma unidade dos estados, das ações e das qualidades, e que ele, enquanto objeto transcendente, é unidade de unidades transcendentes, logo, ele é pressuposto para efetuar a síntese dos estados, ações e qualidades, mas antes é o psíquico que põe esse Ego.

Sartre afirma que os estados psíquicos, além de serem transcendentes, também aparecem à consciência reflexionante. Todavia, é importante salientar o fato de que ao serem objetos de uma reflexão eles não são imanentes ou certos, visto que:

Nós não devemos fazer da reflexão um poder misterioso e infalível, nem acreditar que tudo o que a reflexão atinge é indubitável porque é atingido pela reflexão. A reflexão tem limites de direito e de fato. É uma

23 CARRASCO, Alexandre de Oliveira Torres. Algumas notas sobre realismo e ultra realismo em Sartre. Dois Pontos (UFPR), v. 3, p. 127-157, 2006. 
consciência que põe uma consciência. Tudo o que ela afirma sobre esta consciência é certo e adequado. Mas se outros objetos lhe aparecem através desta consciência, esses objetos não têm nenhuma razão para participar nas características da consciência. ${ }^{24}$

Tais objetos psíquicos devem permanecer transcendentes, dada a pureza pela qual Sartre concebeu o Cogito. Se ele é pura atividade, espontaneidade, consciência de ser consciência dos objetos transcendentes, só podendo ser limitado por si mesmo, esses estados, ações e qualidades devem estar no mundo. O que presenciamos aqui é a insistência de Sartre em manter o Cogito translúcido, espontaneidade que coloca os objetos em sua presença.

Se os estados, ações e qualidades aparecem no nível da consciência reflexionante, eles não têm, como já dissemos, razão nenhuma de participar das características da consciência. Para atestar tal fato, Sartre nos apresentará um exemplo reflexivo de ódio:

Eu vejo Pedro, sinto uma profunda perturbação de repulsão e de cólera ao vê-lo (estou já no plano reflexivo): a perturbação é consciência. Não posso enganar-me quando digo: experimento neste momento uma violenta repulsão por Pedro. Mas o ódio é esta experiência de repulsão? Evidentemente que não: ele não se dá, para além disso, como tal. Com efeito, odeio Pedro há muito e penso que o odiaria sempre. ${ }^{25}$

Com este exemplo, o filósofo deseja mostrar que uma consciência instantânea de repulsão não poderia se apresentar como ódio que extravasa a instantaneidade da consciência. Logo, se o ódio por Pedro aparece ao mesmo tempo que minha repulsão por ele, isso equivale a dizer que tal estado aparece através da minha consciência de repulsão. Mas Sartre atenta para o fato de que ele (o ódio) se dá como não estando limitado a essa experiência imediata que tive, ou seja, tal estado afirma sua permanência de maneira independente, não se submete à lei absoluta da consciência, "para a qual não há distinção entre a aparência e o ser" ${ }^{26}$. Portanto, ao afirmarmos "eu odeio", estamos realizando uma reflexão impura que toma o ódio como imanente, íntimo e infinito. Operar por vias dessa reflexão impura, é, segundo Sartre, um ato irracional que toma os estados como íntimos e imanentes à consciência. Passar da consciência de repulsa ao ódio é operar por meio da mágica, uma vez que não existem relações lógicas entre o ódio e os vividos da consciência. O problema que nos chama atenção é o modo pelo qual os estados aparecem, como já

24 Sartre, J.P. A transcendência do ego. Tradução de Pedro M.S. Alves. Edições Colibri. Lisboa. 1994. p. 59.

25 Id., ibid, p. 60.

26 Id., ibid, p. 60. 
explicitamos acima, de maneira íntima, imanente e tendendo ao infinito.

Doravante, segundo o filósofo, esse laço mágico também deve ser reportado na relação da consciência com o Eu. Se, como já viemos mostrando no decorrer deste trabalho, a consciência prescinde de um Ego, então porque ele aparece de forma íntima e imanente para ela? Em outras palavras, qual a razão de ser do Ego?

Vimos até este ponto que a consciência é pura atividade espontânea, e que por isso dispensa um núcleo que a unifique. Também notamos que os estados psíquicos e o Ego aparecem sob o modo desinencial da imanência, da duração e da intimidade, mas são apenas objetos transcendentes apreendidos por um saber reflexivo que afirma mais do que sabe. Elucidemos então o modo de aparição desse Ego.

Para o filósofo francês, o Ego aparece à reflexão como um objeto transcendente que realiza a síntese permanente do psíquico, ou seja, "o Ego está do lado do psíquico" ${ }^{27}$. É preciso, todavia, fazer notar que esse Ego não é unidade nem suporte do psíquico, pois o que aparece primeiro à consciência são os estados, as ações e as qualidades, e por detrás deles um Eu. Afirmamos com isso que o Eu não realiza a síntese dos objetos psíquicos. Mas, tal Ego, como afirma Sartre, está sempre comprometido com tais objetos. Ele escreve:

O Ego nada é fora da totalidade concreta dos estados e das ações que ele suporta. Sem dúvida que ele é transcendente a todos os estados que unifica, mas não como um X abstrato cuja missão é apenas unificar: é antes a totalidade infinita dos estados e das ações que se não deixa jamais reduzir a uma ação ou a um estado. [...] O Ego, ao contrário, aparece no horizonte dos estados. Cada estado, cada ação dá-se como podendo ser separada, sem abstração, do Ego. ${ }^{28}$

Para Sartre, o Ego é para os objetos psíquicos o que o mundo é para as coisas, ou seja, o Ego aparece sempre no horizonte dos estados, tudo se passa como se não pudéssemos separar o Ego dos estados, qualidades e ações, mas, como veremos, ele é apenas uma paisagem vazia, opaca e de caráter duvidoso.

Tudo se passa como se cada novo estado, ação ou qualidade fosse religado ao Eu como sua origem, mas tais objetos psíquicos são apreendidos pela consciência sem necessidade de tal Eu. O que fica latente no ensaio é que o Ego possui certa espontaneidade degenerada, porque esta não produz nada.

Mas esta espontaneidade não deve ser confundida com a da consciência. Com efeito, o Ego, sendo objeto é passivo. Trata-se, portanto, de

27 Id., ibid, p. 65.

28 Id., ibid, p. 66. 
uma pseudo-espontaneidade que encontraria os símbolos apropriados no brotar de uma fonte, de um gêiser, etc. Isto é o mesmo que dizer que não se trata senão de uma aparência. A verdadeira espontaneidade deve ser perfeitamente clara: ela é o que produz e não pode ser nenhuma outra coisa. [...] A espontaneidade do Ego escapa-se a ela mesma visto que o ódio do Ego, se bem que não podendo existir por si só, possui apesar de tudo uma certa independência em relação ao Ego. De modo que o Ego é sempre ultrapassado pelo que produz, se bem que, de um outro ponto de vista, ele seja o que produz. ${ }^{29}$

Ora, como objeto, esse Ego é passivo. Destarte, sua espontaneidade é falsa, na medida em que ele não produz nada, e, ao contrário, é produzido. O Ego não se põe antes dos objetos psíquicos, mas é posto por meio deles. Ao realizarmos a passagem da consciência de repulsa para o ódio operamos por meio de uma reflexão impura que toma tal estado como imanente, íntimo e inscrito na duração, e um Eu aparece como fruto dessa reflexão. Ele aparece como realizando a síntese desse estado, mas, por tal estado já ter sido apreendido pela consciência, o Eu não tem razão alguma de ser. Parece-nos que essa passagem de uma reflexão pura para uma reflexão impura apresenta-se como uma tentativa de mitigar a espontaneidade da consciência, logo, os objetos psíquicos se apoiam em um Eu, cujo modo desinencial é o de aparecer como os produzindo e sendo íntimo e imanente à nossa consciência.

Apoiados nas linhas anteriores, podemos dizer que primeiro vêm as consciências através das quais se constituem os estados, e, em seguida destes, o Ego. Entretanto, a consciência, ao se aprisionar no mundo, ou seja, ao negar sua espontaneidade, "inverte esta ordem e as consciências são dadas como emanando dos estados e os estados como produzidos pelo Ego" ${ }^{30}$. Pedro M. S. Alves escreve:

[...] o movimento que conduz a constituição do Ego tem como sua origem uma fuga da consciência diante de sua absoluta espontaneidade. Tudo se passa como se a consciência se atemorizasse ao se apreender como uma liberdade que é anterior a toda e qualquer escolha, como uma espontaneidade que está para lá da própria distinção entre atividade e passividade, visto que estas só se compreendem a partir do Ego como polo dos estados e das ações. ${ }^{31}$

29 Id., ibid, p. 69.

30 Id., ibid, p. 70.

31 ALVES, M. S. Pedro. Irrefletido e Reflexão - Observações sobre uma tese de Sartre. Edições Colibri. Lisboa. 1994, pg. 32. 
Parece, segundo o ensaio, que a consciência projeta a sua própria espontaneidade sobre o Eu para, assim, lhe conferir o que Sartre denomina de "um poder criador que lhe é subitamente necessário". Deve-se atentar para o fato de que tal espontaneidade atribuída ao Eu na verdade nada produz. Tal noção de interioridade aplicada pelo Ego não pode se dar no Ego. Logo, ele se entrega à reflexão como interioridade, imanência, porque não podemos acessar seus conteúdos na medida em que esse interior não existe.

Como síntese irracional de atividade e de passividade, o Ego é também síntese de interioridade e transcendência. Ele se apresenta, em um certo sentido, mais "interior" à consciência que os objetos psíquicos. Desse modo, em relação à consciência, o Ego se dá como íntimo. Tudo se passa como se "o Ego fosse da consciência, apenas com esta diferença essencial de ele ser opaco para a consciência" ${ }^{32}$. Contudo, o Ego não é a totalidade das consciências nem realiza a síntese dos objetos psíquicos; antes, afirma tais objetos como imanentes e interiores, ele é o "suporte" desses objetos.

Como conceito vazio, o Ego está destinado a permanecer vazio. Ele aparece à consciência como uma unidade concreta e não como uma simples forma vazia. Fruto da reflexão impura, percebemos nele uma função, que, segundo Sartre, não é tanto teórica, mas prática, qual seja, a de encobrir à consciência a sua própria espontaneidade. Para Sartre, a consciência constitui o Ego como uma falsa representação dela mesma, ou como:

[...] se ela se hipnotizasse com este Ego que ela constitui, se absorvesse nele, como se ela dele fizesse a sua salvaguarda e a sua lei: é graças ao Ego, com efeito, que se poderá efetuar uma distinção entre o possível e o irreal, entre a aparência e o ser, entre o querido e o sofrido. ${ }^{33}$

O que presenciamos no decorrer de A Transcendência do Ego é um constante esvaziamento da consciência e uma constante insistência para o fato de ela ser concebida enquanto espontaneidade absoluta. No final do ensaio, Sartre chama atenção para as implicações morais do Ego. O que devemos deixar claro é o modo como a própria consciência, ao se deparar com a vertiginosa liberdade que a constitui, tenta ofuscar a si mesma por meio de um Eu. Mas estamos perpassados pela liberdade e, ao trazer à tona o conceito de espontaneidade, vemos que todas as nossas ações são frutos dessa liberdade. O filósofo, no fim do ensaio, escreve:

O Mundo não criou o Eu, o Eu não criou o Mundo, eles são dois objetos para a consciência absoluta, impessoal, e é por ela que eles estão ligados. [...] a relação de interdependência que ela estabelece entre o Eu e

32 Id., ibid, p. 72.

33 Id., ibid, p. 80. 
o Mundo basta para que o Eu apareça como "em perigo" diante do Mundo, para que o $\mathrm{Eu}$ (indiretamente e por intermédio dos estados) retire do Mundo todo o seu conteúdo. Nada mais é preciso para fundamentar filosoficamente uma moral e uma política absolutamente positivas. ${ }^{34}$

Por meio deste trecho podemos perceber o modo como nos posicionamos no mundo. Nossa consciência, ao temer sua espontaneidade, ofusca-se por meio de um Eu. Todas as nossas ações e estados são justificados por meio desse Ego. Todavia, percebemos que a consciência não precisa desse Eu, ela unifica a si mesma escapando-se. Nossas ações e estados, ao emanarem de uma reflexão impura, acabam por serem concebidos como mágica, irracionalidade e, poderíamos até mesmo dizer, como um ato de má-fé.

\section{EMOÇÃO ENQUANTO TRANSFORMAÇÃO DO MUNDO}

No Esboço de uma teoria das emoções ${ }^{35}$, Sartre irá criticar tanto a psicologia positiva como a psicanálise, para depois fundamentar uma psicologia fenomenológica. Entretanto, o que nos interessa nesse escrito é o modo pelo qual o filósofo mantém sua descrição da consciência e a maneira pela qual ele nos mostra que a consciência ofusca a si mesma, dessa vez no registro da emoção. Para tal, examinaremos apenas o último capítulo, "Esboço de uma teoria fenomenológica". Veremos que uma descrição da paisagem da consciência revelará o erro comum a quase a totalidade das teorias psicológicas sobre a emoção: o fato de se pensar a consciência afetiva como, desde o início, consciência reflexiva. Entender a emoção enquanto consciência reflexiva é querer esquecer o plano irrefletido da consciência. Em outros termos, é desprezar o saber fenomenológico acerca da intencionalidade da consciência ${ }^{36}$.

Já elucidamos mais acima a consciência, logo, temos em mente que uma emoção também deverá ser um fenômeno, e, com isso, poderemos indicar a realidade essencial do homem.

Para Sartre, a consciência emocional é primeiramente irrefletida, ou seja, ela não é consciência posicional de si e é impessoal. Dessa maneira, o que se apresenta para a consciência emocionada é antes de tudo o mundo. Ela é uma certa maneira de apreender o mundo. O exemplo do filósofo é sugestivo:

\footnotetext{
34 Id., ibid, p. 83.

35 A presente obra pode ser divida da seguinte maneira: uma introdução que procura pôr em cena a critica de Sartre à psicologia de sua época; um comentário referente às concepções tradicionais de se analisar o caso das emoções, sobretudo em Janet, James e Dembo; e uma experiência de psicologia fenomenológica que toma os conceitos de totalidade sintética, significação e espontaneidade da consciência. Logo, a tarefa do fenomenólogo será estudar a significação da emoção.
}

36 Saber este que viemos traçando com ajuda d'A Transcendência do Ego. 
O sujeito que busca a solução de um problema prático está fora, no mundo, ele percebe o mundo a todo instante, através de todos os seus atos. Se fracassa em suas tentativas, irrita-se, sua irritação mesma é ainda uma maneira de como o mundo the aparece. ${ }^{37}$

A emoção não está alocada no registro da consciência reflexiva, mas, como deixamos claro, no da consciência irrefletida. Podemos avançar em nossa análise e, finalmente, definir a emoção. Ela é uma transformação do mundo, pois, "quando os caminhos traçados se tornam muito difíceis ou quando não vemos caminho algum, não podemos mais permanecer num mundo tão urgente e tão difícil" ${ }^{38}$. Há neste trecho a visão severa acerca do comportamento emotivo. O filósofo comenta três casos de consciência emotiva: a tristeza passiva, a tristeza ativa e o medo. Mas nestes três casos permanece o fato de que a emoção se dá como uma resposta ao mundo que se apresenta diante de nós como difícil de ser encarado. A emoção é uma ação diante do mundo que agora se apresenta como terrível, e no qual precisamos continuar agindo.

No pensamento sartreano acerca da emoção podemos dizer que a consciência emocionada se transforma para transformar, por conseguinte, seu objeto. Quando algo nos aparece como insuportável, impossível de ser solucionado, nossa "consciência irrefletida capta agora o mundo de outro modo e sob um novo aspecto, consciência irrefletida que ordena uma nova conduta" ${ }^{39}$. Para Sartre, essa conduta emotiva não é efetiva, ou seja, não tem por finalidade agir realmente sobre os objetos enquanto tal, mas ela tenta conferir a esse objeto uma outra qualidade, uma menor existência ou uma menor presença, ou ainda uma maior presença, dependendo das circunstâncias em que se encontra. Segundo Sartre, o corpo, ao ser dirigido pela consciência, muda suas relações com o mundo para que assim o mundo possa mudar suas qualidades. Ao ficarmos acuados nos lançamos numa nova atitude em relação às nossas ações. Sartre apresenta um exemplo para ilustrar tal atitude frustrada. Lemos:

Um exemplo simples fará compreender essa estrutura emotiva: estendo a mão para pegar um cacho de uvas. Não consigo pegá-lo, está fora do meu alcance. Sacudo os ombros, torno a baixar a mão, murmuro "estão muito verdes" e me afasto. Todos esses gestos, essas palavras, essa conduta, não são percebidos por eles mesmos. Trata-se de uma pequena comédia que represento debaixo do cacho para conferir às uvas a característica "muito verdes", a qual pode servir de sucedâneo à

37 SARTRE, Jean-Paul. Esboço de uma teoria das emoções. Ed. L\&PM, Porto Alegre, 2006, p. 58.

38 Id., ibid, p. 63.

39 Id., ibid, p. 65. 
conduta que não posso executar. Elas se apresentavam, de início, como "uvas a serem colhidas". Mas essa qualidade urgente logo se torna insuportável, porque a potencialidade não pode ser realizada. Essa tensão insuportável, por sua vez, torna-se um motivo para ver na uva uma nova qualidade "muito verde", que resolverá o conflito e suprimirá a tensão. Só que não posso conferir quimicamente essa qualidade às uvas, não posso agir sobre o cacho pelas vias ordinárias. Então capto o amargor da uva muito verde através de uma conduta de aversão. Confiro magicamente à uva a qualidade que desejo. ${ }^{40}$

É por meio deste longo trecho que podemos entender a emoção. Ela é um ato mágico pelo qual a consciência muda suas relações com os objetos. O que devemos frisar é que essa "mágica" tem por objetivo aliviar as tensões que o mundo exerce sobre nós. Ora, se toda consciência é consciência de um objeto qualquer, então no momento que temos consciência das uvas apreendemo-las como sendo "uvas a serem colhidas". Por não conseguirmos realizar tal ação, magicamente, segundo Sartre, apreendemo-las como "uvas verdes". O que ocorre aqui é uma transformação irracional do objeto.

Sartre ainda nos apresentará outros exemplos, levando em consideração os medos passivos e ativos. Mas o que deve ficar claro em todos esses exemplos é essa conduta mágica da consciência que se transforma para transformar o objeto ${ }^{41}$. Em linhas gerais, o medo é uma consciência que visa negar, por meio de uma conduta mágica, um objeto transcendente. Nos refugiamos nas emoções quando o mundo nos aparece como sombrio, logo, "a crise emocional é aqui abandono de responsabilidade" ${ }^{42}$. Daí Sartre, ao definir a emoção, ser severo e dizer que há exagero mágico das dificuldades do mundo. Destarte, concebemos a emoção como uma conduta mágica que visa mudar o mundo, e, para tal, fazemos uso do corpo ${ }^{43}$. A consciência emocionada, por meio do corpo, transforma o mundo para se refugiar nesse "mundo mágico". Negamos, por assim dizer, o princípio de espontaneidade que nos atravessa. Deste modo,

[...] quando todos os caminhos estão barrados, a consciência precipita-se no mundo mágico da emoção, precipita-se por inteiro, degradan-

40 Id., ibid, pp. $65-66$.

41 No caso do medo passivo, ao ver um animal feroz correr em minha direção, desmaio. O desmaio se afigura aqui como um refúgio. Suprimimos o objeto que se apresenta diante da nossa consciência, mas, se só há consciência na exata medida em que ela é consciência de objetos, suprimimos também a própria consciência. São estes os limites de minha ação mágica. O que devemos sublinhar aqui é o modo pelo qual o filósofo concebe a consciência, modo este que podemos ver n'A Transcendência do Ego.

42 Id., ibid, p. 70.

43 "Para compreender bem o processo emocional a partir da consciência, convém lembrar o caráter duplo do corpo, que é por um lado um objeto no mundo, e, por outro, a experiência vivida imediata da consciência." Id., ibid, p. 77. 
do-se; ela é nova consciência diante do mundo novo, e é com o mais íntimo nela que ela o constitui, com essa presença a si mesma, sem distância, de seu ponto de vista sobre o mundo. ${ }^{44}$

A consciência emocionada passa a ser espontaneidade degradada na medida em que muda o mundo para refugiar-se. "Assim a origem da emoção é uma degradação espontânea e vivida da consciência diante do mundo" ${ }^{45}$ : por não conseguir suportar algo, ela procura captar esse algo de uma outra maneira, adormecendo, sonhando. A emoção não é sincera, porque a consciência é sempre consciência não-tética de si mesma, e, dessa maneira, ela não tem consciência de si mesma como se degradando para escapar à pressão do mundo, mas tem apenas consciência posicional dessa degradação que passa para o nível mágico.

Cremos poder dizer que a emoção se apresenta como um certo tipo de reflexão impura e que sua "libertação deve vir de uma reflexão purificadora ou de um desaparecimento total da situação emocionante" ${ }^{46}$. Se assim é, a emoção aparece à consciência sob o signo da duração, da imanência e da intimidade ${ }^{47}$. Mas, como vimos no decorrer de nosso trabalho, a consciência é um completo vazio (transcende-se constantemente para apreender os objetos) regulada pela instantaneidade. Sobre essa passagem ao infinito, Sartre escreve:

Por certo, se percebo bruscamente um objeto como horrível, não afirmo explicitamente que ele permanecerá horrível para sempre. Mas a simples afirmação do horrível como qualidade substancial do objeto já é, nela mesma, uma passagem ao infinito. Agora o horrível está na coisa, no coração da coisa, é sua textura afetiva, é constitutiva dela. Assim, através da emoção, uma qualidade esmagadora e definitiva da coisa nos aparece. [...] O horrível não é apenas o estado atual da coisa, é ameaça quanto ao futuro, estende-se por todo o porvir e o obscurece, é revelação sobre o sentido do mundo. Assim, em cada emoção, uma série de protensões afetivas dirige-se ao futuro para constituí-lo sob um aspecto emocional. ${ }^{48}$

\footnotetext{
44 Id., ibid, p. 78.

45 Id., ibid, p. 79.

46 Id., ibid, p. 81.

47 "O que é constitutivo da emoção é que ela capta no objeto algo que a excede infinitamente. Com efeito, há um mundo da emoção. Todas as emoções têm em comum fazerem aparecer um mesmo mundo, cruel, terrível, sombrio, alegre etc., mas no qual a relação das coisas com a consciência é sempre exclusivamente mágica. [...] Ora, toda qualidade só é conferida a um objeto por uma passagem ao infinito." Id., ibid, p. 81.

48 Id., ibid, p. 82.
} 
Vimos que na emoção a consciência se degrada e transforma de súbito o mundo determinado no qual vivemos em um mundo mágico, onde as coisas se apresentam tendendo ao infinito. Sartre usa a expressão "o homem é sempre um feiticeiro para o homem" 49 para assim mostrar o caráter irracional dessa operação. Portanto, a consciência crê nesse mundo totalmente mágico. Entretanto, é preciso chamar a atenção para o fato de que, se a consciência capta um objeto como tendo qualidades terríveis, é sobre um fundo de mundo que já se revela à consciência como terrível. A consciência pode "ser-no-mundo" de duas maneiras diferentes, quais sejam, o mundo pode aparecer a ela como um complexo organizado ou como uma totalidade não-utensílio, isto é, modificável sem intermediário.

Devemos, portanto, chamar de emoção uma queda brusca da consciência ao mundo mágico. Tal emoção não é um mero acidente, é, antes, um modo de existência da consciência, nesse caso a emoção aparecendo como "estrutura" da consciência. Devemos concluir que a passagem à emoção é uma modificação completa do "ser-no-mundo", ela tem um sentido, significa alguma coisa para a minha vida psíquica, mas essa passagem brusca segue as leis da magia.

\section{CONCLUSÃO: A MORAL SOB A PREFIGURAÇÃO DA ESPONTANEIDA- DE DA CONSCIÊNCIA}

Ajustando as lentes, podemos perceber que existe, tanto no ensaio A Transcendência do Ego como no Esboço para uma teoria das emoções, um certo ofuscamento que a própria consciência realiza. Talvez, como escreveu o filósofo, ao se deparar com sua liberdade vertiginosa, a consciência tente despotencializar a si mesma. Nosso esforço aqui foi mostrar que, em ambos os escritos, a consciência, ao ser concebida enquanto pura atividade e espontaneidade, não precisa de nenhuma outra estrutura para existir, exceto os objetos.

Fica claro que Sartre também tenta mostrar o modo mesmo pelo qual nos colocamos diante do mundo. Ao atribuirmos o peso de nossas ações a um Ego, nos eximimos da culpa, nos escondemos nele. É certo que a consciência emocionada também exprime esse caráter de fuga, quando muda o mundo a fim de torná-lo mais suportável. Todavia, nossas ações aparecem sempre pautadas pela espontaneidade de nossas consciências, nada escapa dela, ela é tudo e nada ao mesmo tempo.

Diante desse fato fenomenológico inegável, devemos conceber uma moral que se paute na estrutura originária da consciência, ou seja, na sua liberdade. Esses dois escritos mostram de que maneira Sartre leva o pensamento fenomenológico ao extremo, acabando por esbarrar em problemas de ordem moral e existencial. Tanto o ensaio como o esboço se

49 Também podemos encontrar esta expressão n'A Transcendência do Ego, quando Sartre comenta acerca do Eu diante da consciência. 
apresentam como os caminhos que constituíram, posteriormente, O Ser e o Nada.

$\mathrm{O}$ Ego aparece à consciência como íntimo para dar suporte aos nossos atos psíquicos; a emoção, no mesmo sentido, transforma a consciência para que esta possa transformar o mundo e torná-lo "mágico", ou seja, suportável. Ambos se apresentam como maneira da própria consciência barrar sua espontaneidade originária. Levando este dado, constituído por vias da fenomenologia, a saber, a noção de espontaneidade, devemos abrir caminho para uma nova maneira de conceber a moral. Se a consciência é essencialmente liberdade, devemos conceber todas as nossas ações como emanando deste dado originário. Sendo o Cogito liberdade e vazio, devemos nos responsabilizar por cada escolha, cada ato, cada ação que exercemos no mundo concreto dos viventes, na exata medida em que os realizamos. Se a consciência é espontaneidade e, por isso mesmo, apreende os objetos em sua instantaneidade, atribuir nestes o futuro e a duração é cair numa mágica profundamente irracional, mágica essa que tem por primazia ofuscar a liberdade à qual estamos todos condenados.

\section{REFERÊNCIAS BIBLIOGRÁFICAS}

BELO, Renato dos Santos. O Paradoxo da liberdade: Psicanálise e História em Sartre. São Paulo: USP, 2006 (Tese de Mestrado).

BORNHEIM, Gerd. Sartre: Metafísica e Existencialismo. São Paulo: Perspectiva, 2000.

CARRASCO, Alexandre de Oliveira Torres . Algumas notas sobre realismo e ultra realismo em Sartre. Dois Pontos (UFPR), v. 3, p. 127-157, 2006.

HUSSERL, Edmund. A Ideia da Fenomenologia. Tradução de Arthur Morão. Lisboa: Edições 70, 2. ed.,1958.

LEBRUN, Gérard. A Filosofia e sua história. São Paulo: Cosaf Naify, 2006.

MOUTINHO, Luiz Damon S. Sartre - Existencialismo e Liberdade (Coleção Logos). São Paulo: Moderna, 1996.

SARTRE, J. P. A transcendência do Ego. Tradução de Pedro M. S. Alves. Lisboa: Edições Colibri, 1994. . Coleção Os Pensadores. São Paulo: Ed. Nova Abril, 1987. . Esboço para uma teoria das emoções. Tradução de Paulo Neves. Ed. L\&PM, Porto Alegre, 2006. 
. O Ser e o Nada. Tradução e notas de Paulo Perdigão. Petrópolis: Ed. Vozes, 1997.

. Uma idéia fundamental da fenomenologia de Husserl: A Intencionalidade. Traduzido por Alexandre de Oliveira Torres Carrasco.

SILVA, Franklin Leopoldo e. Ética e literatura em Sartre: ensaios introdutórios. São Paulo: Ed. UNESP, 2004. - (Coleção Biblioteca de Filosofia). 